\title{
SPATIAL AND TEMPORAL VARIATIONS OF THE CHROMOSOMAL INVERSION POLYMORPHISM OF ANOPHELES FUNESTUS IN SENEGAL
}

\author{
DIA I.***, LOCHOUARN L.*, BOCCOLINI D.***, COSTANTINI C.***,***** \& FONTENILLE D.,******
}

\section{Summary :}

The polymorphism of paracentric inversions of An. funestus polytene chromosomes was studied along a transect in Senegal in order to assess their variations at the spatial and temporal level. There was an increase in the degree of chromosomal polymorphism from the West to South-East. At the geographical level the variations in inversion frequencies were highly significant whatever the chromosomal arm considered. However, the variations in the chromosomal inversion frequencies did not change significantly over either seasons or years, except for inversion $3 \mathrm{~b}$ in the village of Dielmo. Such geographical variability within a relatively limited area, associated to temporal stability, suggest a restricted gene flow between the populations studied, probably due to discontinuities in the An. funestus distribution and to its bioecology.

KEY WORDS : Anopheles funestus, polytene chromosome, chromosomal polymorphism, Senegal.
Résumé : VARIATIONS SPATIO-TEMPORELLES DU POLYMORPHISME CHROMOSOMIQUE D'AN. FUNESTUS AU SÉNÉGAL

Le polymorphisme des inversions paracentriques des chromosomes polytènes $d^{\prime} A n$. funestus a été étudié le long d'un transect au Sénégal dans le but d'estimer leurs variations spatio-temporelles. Un polymorphisme croissant a été observé de l'ovest vers le sudest. À l'échelle géographique, les variations des fréquences des inversions ont été significatives quel que soit le bras chromosomique considéré. Cependant ces variations n'ont été liées ni à la saison ni à l'année à l'exception de l'inversion 36 dans le village de Dielmo. De telles variations des fréquences des inversions chromosomiques à l'intérieur d'une aire limitée, associées à une stabilité temporelle, suggèrent un flux génétique restreint entre les différentes populations étudiées dû probablement aux discontinuités observées dans la distribution et la bioécologie d'An. funestus.

MOTS CLÉS : Anopheles funestus, chromosome polytène, polymorphisme chromosomique, Sénégal.

\section{INTRODUCTION}

A n. funestus Giles is one of the most important vectors of malaria in tropical Africa. Since the thirties, it was found by larval morphology that it belongs to a group of closely related species named funestus group, consisting of An. funestus, An. confusus Evans \& Leeson, An. leesoni Evans, An. fuscivenosus Leeson, An. rivulorum Leeson and $A n$. brucei Service. Gillies \& De Meillon (1968) introduced

\footnotetext{
* Laboratoire d'Entomologie Médicale, Institut de Recherche pour le Développement (IRD), Institut Pasteur, Dakar, Sénégal.

** Département de Biologie Animale, Université Cheikh Anta Diop, Dakar, Sénégal.

*** Istituto Superiore di Sanità, Roma, Italia.

**** Istituto di Parassitologia, Università "La Sapienza", Roma, Italia

${ }^{* * * * *}$ Centre National de Recherche et de Formation sur le Paludisme, Ouagadougou, Burkina Faso.

****** Laboratoire d'Entomologie, Antenne IRD à l'Organisation de Coordination pour la lutte Contre les Endémies en Afrique Centrale (OCEAC), Yaoundé, Cameroun.

Correspondence: Dr Ibrahima Dia, IRD-Institut Pasteur, BP 220, Dakar, Sénégal.

Tel.: + 2218434874 - Fax: + 2218399210

E-mail: diaibra@dakar.ird.sn
}

the term funestus sub-group for An. funestus, $A n$. parensis Gillies, An aruni Sobti and An. vaneedeni Gillies \& Coetzee which are distinguished on the basis of minor characters of the adult. With a few exceptions, fixed or polymorphic chromosomal inversion rearrangements can reliably identify most species of the section. Only An. funestus is a vector of human malaria, but in Tanzania Wilkes et al. (1996) recently found An. rivulorum infected with Plasmodium falciparum. Laboratory experiments have shown that An. vaneedeni is susceptible to malaria infection, but its involvement in natural malaria transmission has not been clearly documented (De Meillon et al., 1977). In Senegal, only An. funestus is reported (Diagne et al., 1994). During studies on malaria transmission and arbovirus surveys in this country, it was found that $A n$. funestus landing on human baits and resting indoors have remarkably high circumsporozoite and anthropophilic rates. A previous study on the chromosomal inversion polymorphism in Senegal showed a high degree of heterogeneity among populations along a latitudinal transect (Lochouarn et al., 1998). This paper provides further information on spatial and temporal patterns of the chromosomal polymorphism from their same sites. 


\section{STUDY AREA}

ix villages were chosen along the northern Gam-

$\circlearrowleft$ bian border. They are located along a transect across the Sudanese and Sudano-Guinean climatic zones (Fig. 1).

The villages of Dielmo $\left(13^{\circ} 45^{\prime} \mathrm{N}, 16^{\circ} 25^{\prime} \mathrm{W}\right)$ and Madina Djikoye $\left(13^{\circ} 38^{\prime} \mathrm{N}, 16^{\circ} 18^{\prime} \mathrm{W}\right)$ are $12 \mathrm{~km}$ apart, and are located in the northern Sudanese zone within the $700-1,000 \mathrm{~mm}$ isohyets. The climate is of Sudanese type, annual rainfall falling during six-seven months from April-May to October, with thermal amplitudes often higher than $25^{\circ} \mathrm{C}$. Maximum temperatures occur in April-May $\left(40^{\circ} \mathrm{C}\right)$ and October $\left(35^{\circ} \mathrm{C}\right)$, while minimum temperatures are lower than $10^{\circ} \mathrm{C}$ in DecemberJanuary, and between 20 and $25^{\circ} \mathrm{C}$ the rest of the year. Kouvar $\left(13^{\circ} 23^{\prime} \mathrm{N}, 13^{\circ} 37^{\prime} \mathrm{W}\right)$ and the Sankagne area $\left(13^{\circ} 24^{\prime} \mathrm{N}, 13^{\circ} 45^{\prime} \mathrm{W}\right)$ are $1.6 \mathrm{~km}$ apart, and are situated in the southern Sudanese zone within the 1,000$1,300 \mathrm{~mm}$ isohyets. The rainy season lasts here from June to October. The vegetation is composed by shrubs and open wooded savanna replacing the climatic forest which formerly covered the area, and whose vestiges are left in relic areas. Degradation of the natural vegetation is due to the combined action of persistent rainfall deficit and the extension of cultivated areas.

Wassadou $\left(13^{\circ} 21^{\prime} \mathrm{N}, 13^{\circ} 20^{\prime} \mathrm{W}\right)$ and the Kédougou region $\left(12^{\circ} 33^{\prime} \mathrm{N}, 12^{\circ} 11^{\prime} \mathrm{W}\right)$ are located in the SudaneseGuinean zone. This is the wettest in the country, with one period of precipitation from June to November, and mean annual rainfall ranging $1,300-1,800 \mathrm{~mm}$. The thermal amplitude is $20^{\circ} \mathrm{C}$, with maximum temperatures of $35^{\circ} \mathrm{C}$ and $30^{\circ} \mathrm{C}$ in June and October, and minimum temperatures of $15^{\circ} \mathrm{C}$ and $25^{\circ} \mathrm{C}$ in December-January and in August, respectively. Natural climatic vegetation is a dense forest. Under the actions of humans this has almost completely disappeared for

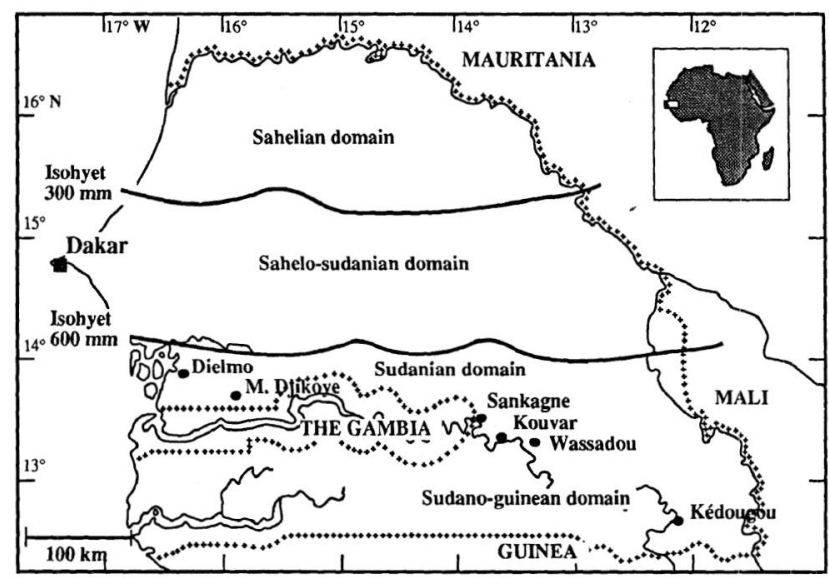

Fig. 1. - Location of the study area. the benefit of rice and groundnut cultures in the floodplains.

\section{MATERIALS AND METHODS}

$\mathrm{D}$ aytime indoor resting adult An. funestus were collected from all the six localities by pyrethrum spray catches from April 1994 until November 1998. Upon capture, half-gravid females were sorted and immediately fixed in modified Carnoy's fixative (three parts pure ethanol: one part glacial acetic acid), held for 24 hours at ambient temperature, and then stored at $-20^{\circ} \mathrm{C}$ until processing. Polytene chromosome preparations from the nurse ovarian cells were obtained following the method of Coluzzi (1968) modified by Hunt (1973). Paracentric inversions were identified by microscopic examination and scored following the nomenclature of Green \& Hunt (1980), Boccolini et al. (1998), and Lochouarn et al. (1998). Inversions frequencies and karyotypic differences among populations were assessed using the Genepop v. 1.2 software (Raymond \& Rousset, 1995).

\section{RESULTS}

\section{CHROMOSOMAL INVERSION POLYMORPHISM}

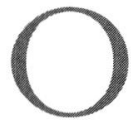
bservations of polytene chromosomes were carried out on 611 specimens. The whole polytene complement could be read in 422 speci-

mens.

In the study area, the analysis of the chromosomal polymorphism has been reported in a previous paper (Lochouarn et al., 1998); this can be summarised as follows: depending on the village, An. funestus showed variable levels of polymorphism for ten paracentric inversions producing the following arrangements: six on chromosomal arm 2 (a, s, t, ab, au, tz), three on chromosomal arm 3 ( $a, b, a b)$ and one on chromosomal arm 5 (a).

\section{GEOGRAPHICAL VARIATION}

The chromosomal inversions observed showed clear geographical variations among the various localities, with highly significant differences.

In Dielmo and Madina Djikoye, all the 168 specimens examined were carriers of the standard arrangement on chromosomal arm 2 (Table I). In Kouvar, the inversion $2 \mathrm{a}$ was the most frequent (percent frequency: $32.14 \%$ ). The inversion $2 \mathrm{~s}$ was the only one present in Sankagne (96.49\%). The inversions 2a and 2t were predominant in Wassadou and the Kédougou area. In the latter, all inversions were observed but inversion 


\begin{tabular}{|c|c|c|c|c|c|c|c|c|c|c|c|c|c|c|c|c|}
\hline \multirow[b]{2}{*}{ Locality } & \multirow{2}{*}{$\begin{array}{c}\text { Sample } \\
\text { size }\end{array}$} & \multicolumn{7}{|c|}{ Chromosomal arm 2} & \multirow{2}{*}{$\begin{array}{c}\text { Sample } \\
\text { Size }\end{array}$} & \multicolumn{4}{|c|}{$\operatorname{arm} 3$} & \multirow{2}{*}{$\begin{array}{c}\text { Sample } \\
\text { Size }\end{array}$} & \multicolumn{2}{|c|}{$\operatorname{arm} 5$} \\
\hline & & + & a & s & $\mathrm{t}$ & $\mathrm{ab}$ & au & $\mathrm{tz}$ & & + & a & $b$ & $a b$ & & + & a \\
\hline Dielmo & 320 & 100 & - & - & - & - & - & - & 302 & 81.46 & 4.30 & 14.24 & - & 318 & 60.69 & 39.31 \\
\hline M. Djikoye & 16 & 100 & - & - & - & - & - & - & 12 & 100 & - & - & - & 18 & 50 & 50 \\
\hline Sankagne & 114 & 3.51 & - & 96.49 & - & - & - & - & 112 & 100 & - & - & - & 114 & 71.05 & 28.95 \\
\hline Kouvar & 28 & 14.29 & 32.14 & 28.57 & 25 & - & - & - & 32 & 43.75 & - & 21.88 & 34.37 & 28 & 75 & 25 \\
\hline Wassadou & 8 & - & 62.50 & - & 37.50 & - & - & - & 8 & - & - & 12.50 & 87.50 & 8 & 25 & 75 \\
\hline Kedougou & 324 & 1.23 & 45.68 & - & 42.28 & 5.56 & 1.85 & 3.40 & 374 & - & 0.53 & 2.41 & 97.06 & 360 & 46.94 & 53.06 \\
\hline Total & 810 & 42.96 & 20 & 14.57 & 18.15 & 2.22 & 0.74 & 1.36 & 840 & 45.24 & 1.78 & 7.62 & 45.36 & 844 & 56.16 & 43.84 \\
\hline
\end{tabular}

Sample size $=$ number of chromatids.

Table I. - Geographical variability of chromosomal inversion frequencies in indoor resting samples of half-gravid females of An. funestus from various localities in Senegal.

$2 \mathrm{~s}$; the inversions $2 \mathrm{a}$ and $2 \mathrm{t}$ were predominant at frequencies of $45.68 \%$ and $42.28 \%$, respectively (Table I). The variations in inversion frequencies were highly significant $(P<0.0001)$.

On the chromosomal arm 3 in Wassadou and Kédougou the inversions $\mathrm{a}$ and $\mathrm{b}$ were in linkage disequilibrium. The inverted homokaryotype $3 \mathrm{ab} / \mathrm{ab}$ was observed in Kouvar together with the standard $3^{+/+}$. In Sankagne, as in Dielmo and Madina Djikoye, the standard arrangement was very common, whereas the inverted arrangement $3 \mathrm{ab}$ was never observed (Table I). As found for the chromosomal arm 2, the variations in inversion frequencies on the chromosomal arm 3 were statistically significant $(P<0.001)$. The inversion 5 a was observed in all the populations under study, being most prevalent in Wassadou and Kédougou (Table I), and showing an overall highly significant variability $(P<0.001)$.

\section{SEASONAL VARIATION}

The only data available to evaluate seasonal variations in the inversion frequencies were obtained from Dielmo, where breeding of An. funestus is continuous the year round. The most important samples for this analysis were obtained in 1995 and 1996. During the first year, sampling was carried out by periodic transversal surveys, whereas in 1996 it was performed longitudinally throughout the year. Our analysis, however, relate only to chromosomal arms 3 and 5 , since arm 2 was found monomorphic standard in Dielmo. Inversions $3 \mathrm{a}$ and $3 \mathrm{~b}$ were recorded during both the rainy and dry seasons, with the exception of the 1996 rainy season when inversion $3 \mathrm{a}$ was not observed. For all the periods considered, the standard arrangement was always the most frequent, followed by inversion $3 \mathrm{~b}$ (Table II). The differences in inversion frequencies between the dry and the rainy seasons were not significant either in $1995(P=0.21)$ or in $1996(P=0.08)$. No difference was observed either between the dry seasons 1995-1996 ( $P=0.31)$, or between the rainy season samples 1995-1996 $(P=0.12)$. As found for the

\begin{tabular}{|c|c|c|c|c|c|c|c|c|}
\hline \multirow[b]{2}{*}{ Period } & \multirow{2}{*}{$\begin{array}{c}\text { Sam- } \\
\text { ple } \\
\text { size }\end{array}$} & \multicolumn{4}{|c|}{$\operatorname{arm} 3$} & \multirow{2}{*}{$\begin{array}{l}\text { Sam- } \\
\text { ple } \\
\text { size }\end{array}$} & \multicolumn{2}{|c|}{$\operatorname{arm} 5$} \\
\hline & & + & a & $\mathrm{b}$ & $a b$ & & + & a \\
\hline $\begin{array}{c}\text { Dry season } \\
1995\end{array}$ & 32 & 71.88 & 12.50 & 15.63 & - & 32 & 56.25 & 43.75 \\
\hline $\begin{array}{c}\text { Rainy season } \\
1995\end{array}$ & 54 & 87.04 & 5.56 & 7.41 & - & 54 & 55.56 & 44.44 \\
\hline $\begin{array}{c}\text { Dry season } \\
1996\end{array}$ & 44 & 63.64 & 6.82 & 29.55 & - & 46 & 52.17 & 47.83 \\
\hline Rainy season & 40 & 82.50 & - & 17.50 & - & 42 & 50 & 50 \\
\hline Total & 170 & 77.06 & 5.88 & 17.06 & - & 174 & 53.45 & 46.55 \\
\hline
\end{tabular}

Sample size $=$ number of chromatids

Table II. - Seasonal variability of chromosomal inversion frequencies in indoor resting samples of half-gravid females of An. funestus from Dielmo.

inversions on chromosomal arm 3, the differences in frequencies for inversion 5 a were not significantly different either between the dry and rainy season samples ( $P=0.87$ in 1995, and $P=0.84$ in 1996), or between samples from successive years $(P=0.72$ among dry seasons, and $P=0.73$ among rainy seasons).

\section{ANNUAL VARIATION}

In Dielmo, the standard arrangement was always the prevalent one on arm 3. The inversion 3a was observed at frequencies ranging from $1.22 \%$ in 1998 to $12.50 \%$ in 1994 (Table III). The inversion 3b was observed at frequencies often $>10 \%$ with differences that were statistically significant $(P<0.01)$. On arm 5 , the standard arrangement was the prevalent one in all years. The variations in frequency of this inversion were at the threshold of signification $(P=0.05)$.

In the Kédougou area, with the exception of inversion 2ab which was not observed in 1996, and of inversion 2s which was never found, all other inversions were observed on arm 2 during the four years of study (Table IV). Inversions 2a and 2t were always the most frequent whatever the year considered, while inversions $2 \mathrm{au}$ and $2 \mathrm{tz}$ were always rare (frequencies $<5 \%$ ). 


\begin{tabular}{|c|c|c|c|c|c|c|c|c|}
\hline \multirow{2}{*}{ Year } & \multirow{2}{*}{$\begin{array}{c}\text { Sample } \\
\text { size }\end{array}$} & \multicolumn{4}{|c|}{$\operatorname{arm} 3$} & \multirow{2}{*}{$\begin{array}{c}\text { Sample } \\
\text { size }\end{array}$} & \multicolumn{2}{|c|}{$\operatorname{arm} 5$} \\
\hline & & + & a & b & $a b$ & & + & a \\
\hline 1994 & 8 & 50 & 12.50 & 37.50 & - & 8 & 62.50 & 37.50 \\
\hline 1995 & 86 & 81.40 & 8.14 & 10.47 & - & 86 & 55.81 & 44.19 \\
\hline 1996 & 84 & 72.62 & 3.57 & 23.81 & - & 88 & 51.14 & 48.86 \\
\hline 1997 & 42 & 83.33 & 2.38 & 14.29 & - & 40 & 75 & 25 \\
\hline 1998 & 82 & 92.68 & 1.22 & 6.10 & - & 96 & 67.71 & 32.29 \\
\hline Total & 302 & 81.46 & 4.30 & 14.24 & - & 318 & 60.69 & 39.31 \\
\hline
\end{tabular}

Sample size $=$ number of chromatids

Table III. - Annual variability of chromosomal inversion frequencies in indoor resting samples of half-gravid females of An. funestus from Dielmo.

No statistically significant difference was found in the variation in frequency of these inversions $(P=0.52)$. On chromosomal arm 3, both inversions $3 \mathrm{~b}$ and $3 \mathrm{ab}$ were observed at high frequency during all years of the study (Table IV). The variation in frequency was not significant between the four years of the study $(P=0.95)$. The inversion $5 \mathrm{a}$ was more frequent than its corresponding standard arrangement during every year, except in 1997 when it was observed at a frequency of exactly $50 \%$ (Table IV). These changes in frequency were not significantly different $(P=0.13)$.

\section{DISCUSSION}

T The chromosomal analysis showed that contrary to what is generally assumed (Gillies \& De Meillon, 1968), An. funestus is a very polymorphic species. On the chromosomal arms carrying inversions, i.e. 2, 3 and 5, we observed seven, four and two arrangements, respectively. Most of these arrangements were already reported in the pioneer work of Green \& Hunt (1980) from samples collected in Nigeria, South Africa, Zimbabwe, Namibia and Kenya. Indeed, of the six inversions on arm 2 that were described by these authors, only the inversions $2 \mathrm{a}$ and $2 \mathrm{~b}$ were found in our Senegalese samples, whereas the inversions c, d, $\mathrm{e}$ and $\mathrm{h}$ were not observed. Among the three inversions described on arm 3 , only the $3 \mathrm{a}$ and the $3 \mathrm{~b}$ were observed, whereas the $3 \mathrm{c}$ was not found. On arm 5 , only the inversion 5 a was found, whereas the $5 \mathrm{~b}$ was not observed.

No inversion was observed on the $\mathrm{X}$ heterosome and on $\operatorname{arm} 4$, as found in previous studies on the cytogenetics of An. funestus (Green \& Hunt, 1980; Boccolini et al., 1992, 1994, 1998). Our study, therefore, further supports the evidence of a monomorphism of these two portions of the polytenic complement.

The inversions $2 \mathrm{~s}, 2 \mathrm{t}$ and $2 \mathrm{u}$ were previously described from specimens collected in Mali and Burkina Faso (Boccolini et al., 1998). Inversion $2 \mathrm{z}$ is a new inversion based on inversion $2 t$ reported so far only from Senegal (Lochouarn et al., 1998). In Burkina Faso, the inversion $2 \mathrm{~s}$ was observed in some villages at a frequency of $3.7 \%$ (Boccolini et al., 1994). The inversion 2t was observed there at a very low frequency: only two heterozygotes were found out of 186 specimens examined from Diarabakoko, southern Burkina Faso. In the village of Banambani, in southern Mali, the inversions $2 \mathrm{a}$ and $2 \mathrm{t}$ were the most prevalent in 78 readable preparations at frequencies of $62.1 \%$ and $25.0 \%$. The inversions 2ab and $2 \mathrm{au}$ accounted for another $6.4 \%$ and $5.7 \%$, respectively. In Madagascar, only the inversion 2a was observed at frequencies ranging from $2.0 \%$ in Tulear to $32.5 \%$ in Mandoto (Boccolini et al., 1992). On chromosomal arm 3 , the standard arrangement was the prevailing one in Dielmo, Madina Djikoye, and Sankagne. These observations are comparable to those of Green (1982) who reported that at Wallikunda, in The Gambia, the arm 3 was monomorphic except for inversion $3 \mathrm{a}$ found at a relative frequency of $6.0 \%$. In Kédougou and Wassadou, the inverted arrangement $3 \mathrm{ab}$ was always prevalent. These two inversions occur at greatly different frequencies throughout Africa (in South Africa, Green \& Hunt, 1980; in Madagascar, Boccolini et al., 1992; in Mali, Boccolini et al., 1998; and in Burkina Faso, Costantini et al., 1999). In Banambani, inversion $3 \mathrm{~b}$ is apparently fixed and inversion $3 a$ nearly so, most of the speci-

\begin{tabular}{|c|c|c|c|c|c|c|c|c|c|c|c|c|c|c|c|c|}
\hline \multirow[b]{2}{*}{ Year } & \multirow{2}{*}{$\begin{array}{c}\text { Sample } \\
\text { size }\end{array}$} & \multicolumn{7}{|c|}{ Chromosomal arm 2} & \multirow{2}{*}{$\begin{array}{l}\text { Sample } \\
\text { size }\end{array}$} & \multicolumn{4}{|c|}{$\operatorname{arm} 3$} & \multirow{2}{*}{$\begin{array}{l}\text { Sample } \\
\text { size }\end{array}$} & \multicolumn{2}{|c|}{$\operatorname{arm} 5$} \\
\hline & & + & $\mathrm{a}$ & $s$ & $\mathrm{t}$ & $a b$ & $\mathrm{au}$ & $\mathrm{tz}$ & & + & a & $\mathrm{b}$ & $\mathrm{ab}$ & & + & $\mathrm{a}$ \\
\hline 1994 & 46 & 4.35 & 32.61 & - & 45.65 & 10.87 & 2.17 & 4.35 & 56 & - & - & 3.57 & 96.43 & 52 & 42.31 & 57.69 \\
\hline 1996 & 32 & - & 56.25 & - & 37.50 & - & 3.13 & 3.13 & 38 & - & - & 2.63 & 97.37 & 36 & 61.11 & 38.89 \\
\hline 1997 & 174 & 1.15 & 48.85 & - & 40.80 & 4.60 & 1.72 & 2.87 & 196 & - & 0.51 & 2.04 & 97.45 & 190 & 50 & 50 \\
\hline 1998 & 72 & - & 41.67 & - & 45.83 & 6.94 & 1.39 & 4.17 & 84 & - & 1.19 & 2.38 & 96.43 & 82 & 36.59 & 63.41 \\
\hline Total & 324 & 1.23 & 45.68 & - & 42.28 & 5.56 & 1.85 & 3.40 & 374 & - & 0.53 & 2.41 & 97.06 & 360 & 46.94 & 53.06 \\
\hline
\end{tabular}

Sample size $=$ number of chromatids

Table IV. - Annual variability of chromosomal inversion frequencies in indoor resting samples of half-gravid females of An. funestus from the Kedougou area. 


\begin{tabular}{|c|c|c|c|c|c|c|c|c|c|c|c|c|c|c|c|c|}
\hline \multirow[b]{2}{*}{ Zone } & \multicolumn{11}{|c|}{ Chromosomal arm 2} & \multicolumn{2}{|c|}{$\operatorname{arm} 3$} & \multicolumn{2}{|c|}{$\operatorname{arm} 5$} & \multirow[b]{2}{*}{ References } \\
\hline & $\mathrm{a}$ & b & c & $\mathrm{d}$ & e & $\mathrm{h}$ & $\mathrm{s}$ & $\mathrm{t}$ & $a b$ & $\mathrm{au}$ & $\mathrm{tz}$ & a & $\mathrm{b}$ & a & $\mathrm{b}$ & \\
\hline East and South Africa & + & + & + & + & + & + & & & & & & + & + & + & + & Green \& Hunt, 1980 \\
\hline Madagascar & + & & & & & & & & & & & + & + & + & & Boccolini et al., 1992 \\
\hline Burkina Faso & + & & & & & & + & + & & & & + & + & + & & $\begin{array}{l}\text { Boccolini et al., } 1994 \\
\text { Costantini et al., } 1999\end{array}$ \\
\hline Mali & + & & & & & & & + & + & + & & + & + & + & & Boccolini et al., 1998 \\
\hline Senegal & + & & & & & & + & + & + & + & + & + & + & + & & Lochouarn et al., 1998 \\
\hline
\end{tabular}

Table V. - Summary of the different inversions described in An. funestus from South and East Africa, West Africa and Madagascar island.

mens analysed so far being homozygotes $3 \mathrm{ab} / \mathrm{ab}$. In our study, this arrangement was observed only in the south-east of Senegal, in particular in Kouvar, Wassadou, and Kédougou. In Madagascar the inversion $3 \mathrm{a}$ was the only one observed at frequencies varying between $21.9 \%$ at Ankotrofotsy to $59.1 \%$ at Anjiro.

The chromosomal arm 5 is polymorphic for the inversion 5a; the inverted arrangement was prevalent in Wassadou and Kédougou, whereas in Dielmo, Madina Djikoye, Kouvar, and Sankagne the standard arrangement was prevalent. All the different inversions described in An. funestus are summarized in Table V.

At the geographical level, the variations of the relative frequencies of the chromosomal inversions observed on arms 2, 3 and 5 were all significant. Along our transect, there was an increase in the degree of chromosomal polymorphism from the West to the South-East, i.e. from Dielmo to the Kédougou area. These results differ from those obtained by Costantini et al. (1999) in Burkina Faso where no clinal variability was observed. In Dielmo, the seasonal variations in the chromosomal inversion frequencies were not significant either for the chromosomal arm 3 or 5 . In Madagascar, however, temporal differences in the frequency of the inversions $2 \mathrm{a}$ and $3 \mathrm{a}$ were observed by Boccolini $e t$ al. (1992) in Mandoto. On arm 3, the year-to-year changes in frequencies were significant in Dielmo, whereas in the zone of Kédougou no variation was observed on arms 2, 3 and 5. In the chromosomal form Mopti of An. gambiae s.s. Giles, Touré et al. (1994) reported how in Mali the chromosomal inversions $2 \mathrm{Rbc}$ and $2 \mathrm{Ru}$ show consistent and clinal geographical and temporal fluctuations, suggesting an adaptive role of these arrangements for more arid and humid conditions, respectively. Similarly, we observed geographical heterogeneities in the frequency of $A n$. funestus inversions on chromosomal arms 2 and 3 in the two different climatic zones, but temporal stability for most of the arrangements in spite of the large degree of seasonality. The stability of the chromosomal polymorphism at seasonal and annual levels in spite of the heterogeneity at the geographical level could be explained by the patchy distribution of An. funestus, as suggested by Collins et al. (1994). Limitations in dispersal ability could constitute a barrier to the diffusion of genes of resistance to insecticides, as well as genes of interest for disease control using transgenic mosquitoes. An alternative explanation, not mutually exclusive, is that proposed by Costantini et al. (1999) who suggested that An. funestus in Burkina Faso is constituted by two taxa that are sympatric in the strictest sense, and have limited, if any, genetic exchange. They were provisionally named with a non-Linnean nomenclature chromosomal forms Kiribina and Folonzo. The former would be characterized uniquely by inversion $2 \mathrm{~s}$ and by a low degree of polymorphism at all inversions, whereas the latter would be characterized by a much higher degree of polymorphism at all inversions and by inversions $3 \mathrm{a}$ and $3 \mathrm{~b}$ nearly fixed. According to their hypothesis, therefore, our samples could be interpreted as pure (or nearly so) populations of one or the other of the two chromosomal forms. The Dielmo, Madina Dikoye, and Sankagne populations would fall under the definition given for the Kiribina form, whereas populations from Wassadou and the Kédougou area would fall under the definition of the Folonzo form. Lochouarn et al. (1998) demonstrated that by pooling these two groups together, there was a significant departure from Hardy-Weinberg equilibrium due to a deficit of heterokaryotypes. The village of Kouvar, however, may represent a zone of sympatry of both forms, where departures from the Hardy-Weinberg equilibrium have been difficult to detect so far due to the low sample size available. The temporal stability in the degree of polymorphism might then be associated to the more stable nature of the An. funestus larval environment. The use of more polymorphic tools such as microsatellite markers currently under development (Besansky, personal communication) could help to discern between these hypotheses.

\section{ACKNOWLEDGEMENTS}

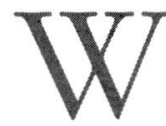

e thank Mr Mamoudou Diallo for his technical assitance, Pr Mario Coluzzi for his collaboration, Dr Vincent Robert for very helpful suggestions, and the villagers for their coope- 
ration throughout the survey. This investigation received financial support from the UNDP/World Bank/WHO Special Programme for Research and Training in Tropical Diseases (TDR), a part of the MIM project ID 9801 01/ WHO TDR 053 S.2 on "Population structure of Anopheles gambiae and Anopheles funestus in Kenya and West Africa", the Institut de Recherche pour le Développement (IRD), and the Institut Pasteur de Dakar.

\section{REFERENCES}

Boccolini D., Rakotoson R., Ralisoa O., Sabatini A., RanDRIANARISOA E. \& Coluzzi M. Polimorfismo cromosomico di Anopheles funestus in Madagascar. Parassitologia, 1992, 34 (Supplement 1), 14-15.

Boccolini D., Sabatini A., Sanogo E., Sagnon N., Coluzzi M. \& Costantini C. Chromosomal and vectorial heterogeneities in Anopheles funestus in Burkina Faso, West Africa. Parassitologia, 1994, 36 (Supplement 1), 20.

Boccolini D., SAgnon N. \& Toure Y.T. Chromosomal polymorphism in Anopheles funestus and description of new inversions in Burkina Faso and Mali. Parassitologia, 1998, 40 (Supplement 1), 14.

Collins F.H., Besansky N. \& Paskewitz S.M. Peut-on espérer interrompre la transmission du paludisme par des vecteurs génétiquement modifiés? Annales de l'Institut Pasteur, 1994, 5 (4), 324-329.

Coluzzi M. Cromosomi politenici delle cellule nutrici ovariche nel complesso gambiae del genere Anopheles. Parassitologia, 1968, 10, 179-183.

Costantini C., Sagnon N.F., Sanogo E., Coluzzi M. \& BocColini D. Chromosomal and bionomic evidence for incipient speciation in Anopheles funestus from Burkina Faso. Parassitologia, 1999, 41, in press.

De Meillon B., Van Eeden G.J., Coetzee L., Coetzee M., MeisWINkel R., Du ToIT C.N.L. \& Hansford C.F. Observations on a species of Anopheles funestus subgroup, a suspected exophilic vector of malaria parasites in northeastern Transvaal, South Africa. Mosquito News, 1997, 37 (4), 657-661.

Diagne N.A., Fontenille D., Konaté L., Faye O., Traore-Lamizana M., Molez J.F. \& Trape J.F. Les anophèles du Sénégal. Liste commentée et illustrée. Bulletin de la Société de Pathologie Exotique, 1994, 87, 1-9.

Gillies M.T. \& Coetzee M. A Supplement to the Anophelinae of Africa South of The Sahara. Publication of The South African Institute for Medical Research, 1987, 55, 143 pages.

Gillies M.T. \& De Meillon B. The Anophelinae of Africa South of the Sahara, 2nd edition. Publication of The South African Institute for Medical Research, 1968, 54, 343 pages.

GREEN C.A. \& HunT R.H. Interpretations of variation in ovarian polytene chromosomes of Anopheles funestus Giles, A. parensis Gillies and A. aruni. Genetica, 1980, 51, 187195.

GreEN C.A. Cladistic analysis of chromosome data Anopheles (Cellia) Myzomyia. Journal of Heredity, 1982, 73, 2-11.
Hunt R.H. A cytological technique for the study of Anopheles gambiae complex. Parassitologia, 1973, 15, 137-139.

Lochouarn L., Dia I., Boccolini D., Coluzzi M. \& Fontenille D. Bionomical and cytogenetical heterogeneities of Anopheles funestus in Senegal. Transactions of The Royal Society of Tropical Medicine and Hygiene, 1998, 92, 607612.

Raymond M. \& Rousset F. Genepop V. 1.2.: a population genetics software for exact test and ecumenicism. Journal of Heredity, 1995, 86, 248-249.

Touré Y.T., Petrarca V., Traoré S.F., Coulibaly A., Maiga H.M., Sankare O., Sow M., Di Deco M.A. \& Coluzzi M. Ecological genetic studies in the chromosomal form Mopti of Anopheles gambiae s.str. in Mali, West Africa. Genetica, 1994, 94, 213-223.

Wilkes T.J., Matola Y.G. \& Charlwood J.D. Anopheles rivulorum, a vector of human malaria in Africa. Medical and Veterinary Entomology, 1996, 10, 108-110.

Reçu le 18 janvier 2000

Accepté le 23 mai 2000 